\title{
What is religion? An African understanding
}

Author:

Jaco Beyers ${ }^{1,2}$

\section{Affiliations:}

${ }^{1}$ The Africa Institute for Missiology, Pretoria,

South Africa

${ }^{2}$ Hervormde Teologiese Kollege, University of Pretoria, South Africa

\section{Correspondence to:} Jaco Beyers

email:

jaco.beyers@gmail.com

\section{Postal address:}

PO Box 14125, Lyttelton

0140, South Africa

\section{Keywords:}

African Traditional

Religion; definition; religion; understanding

Christianity; Western ideals

\section{Dates:}

Received: 01 Sept. 2009

Accepted: 24 Oct. 2009

Published: 10 June 2010

How to cite this article: Beyers, J., 2010, 'What is religion? An African understanding', HTS Teologiese Studies/ Theological Studies 66(1), Art. \#341, 8 pages. DOI: 10.4102/hts.v66i1.341

\section{This article is available} at: http://www.hts.org.za

\section{Note:}

This paper was presented at the 9th European Association for the Study of Religion (EASR) Conference held on 14-17 September 2009 at the University of Messina, Italy.

(C) 2010. The Authors. Licensee: OpenJournals Publishing. This work is licensed under the Creative Commons Attribution License.

\section{ABSTRACT}

Western thought has influenced the way that religion is understood. Western philosophy supported the separation between the sacred and the profane. Modernism, focusing on human rationality, reduced religion to a set of correctly formulated dogmas and doctrines. Western thought, dominated by Christianity, created a hierarchical structure of world religions through a theology of religions. Can an African understanding of religion make a contribution to the understanding of what religion is? Such a question requires an African understanding of religion, as well as an understanding of African religion. From an African perspective, religion emphasises the human effort to systematise, in society, the continuation of a religious experience relevant to a specific context. Tradition, expressed in rituals and ethics, becomes the social expression of these religious experiences. African religion tends not to differentiate the transcendental from the earthly. African scholars do not present one unified understanding of religion. Some scholars would even argue that an African understanding is nothing more than an internalised form of Western perspectives. To characterise African Traditional Religion as a separate type of religion minimises the contribution that an African understanding can make to religion.

\section{INTRODUCTION}

\section{Defining the problem}

\section{African religion and the West}

Over the centuries there have been attempts to define the phenomenon of religion. These attempts have come from various perspectives, ranging from the psychological, sociological and anthropological to the philosophical and theological (Momen 1999:52-73) and, most recently, they have come from a biological perspective (Hammer 2005). Not only can these attempts be arranged according to perspectives, but also according to theories (Crosby 1981:5), providing definitions for the groups of definitions. Although varied, the theories and definitions became fixed in stereotypical forms. As a result of the confusion caused by the plethora of definitions there have even been suggestions to discard the mostly dominant Western term 'religion' altogether (Asad, cited in Figl 2003:71).

The majority of definitions of, and theories on, religion have originated from a Western background. Even the whole existence of the term 'religion' is seen as a 'eurozentrischen' (Eurocentric) term (Figl 2003:73). Sundermeier (1999:11) points out that the mere question about what religion is betrays a Western background. Thus, a whole world of Western-determined references is implied when talking about religion, but such a so-called Western understanding of religion is not necessary homogenous.

The dominant religion of the West has been Christianity. The result is that a Christian (Western) understanding of religion dominated the scholarly field. There are those who now believe that there are no proper equivalents to the term 'religion' in other cultures (Figl 2003:73). A Christian theology of religions led Western scholars to arrange religions in a hierarchical structure, implying that some religions were inferior to others (Momen 1999:69).

The typology of religion as a result of Western scholarship led to a categorisation of religion according to levels of development. The discovery of new cultures and continents during the 17th and 18th centuries created a dilemma concerning the relation between religions. Western thought on this led to the creation of a category named 'primal' or 'traditional' religions. This category was used to group religions together that showed similarities in structure. The premise for this categorisation was the acceptance of the evolutionistic development of religions. The earliest religion in 'original' form could be discovered by studying religious practices of contemporary tribal societies (Thorpe 1992:5). The assumption was that some religions progressed in development and others did not. The underdeveloped religions were pejoratively referred to as primal, traditional or primitive, or even tribal, religions (Sundermeier 1999:31).

Even in efforts to try to understand African religions, scholars have 'abstracted African religions from their cultural and historical contexts' (Westerlund 1993:59). Scholars of religion, as well as anthropologists, 'had a tendency to "Westernize" African religions' (Westerlund 1993:59).

Magesa (2002) points out that Western scholars defined African religion in terms of Western philosophy. 'If there was such a thing approximating religion at all in Africa, they [Western scholars] argued, it was "animism" or "fetishism", a multiplicity of ritual actions with natural objects as deities' (Magesa 2002:14-15). The purpose of missionaries in such conditions was to 'do away with' this religion based on superstition and convert Africans to the God known by Europeans.

African Traditional Religion is part of the category designated as primal religion (Momen 2009:356). A major characteristic of primal religions is the fact that they originated and developed in relative isolation from other cultures (Thorpe 1992:5). Thorpe (1992:5) also lists the following as further characteristics of 
a primal religion:

- It is a religion found among societies consisting of relatively small groups of individuals who are heavily dependent on one another, as such, Wernhart (cited in Figl 2003:260) and Sundermeier (1999:31) talk about 'tribal societies'.

- Society is dependent on nature.

- Society does not have a (long) history of written culture.

- Metaphors, symbolism and art play an important role in that culture.

- The religion does not have a specific founder.

As this study does not intend to discuss primal religions, it is important to note that African Traditional Religion must be understood as belonging to a specific category. It does not make African Traditional Religion unique, but it does make us aware that different cultural-religious groups understand religion differently. This study is concerned with the way in which African Traditional Religion can contribute to the understanding of the phenomenon of religion.

\section{Africa and other religions}

Can an understanding of African religion and an African understanding of religion contribute to the debate? There are many answers to this question, in that there are those who would say that African scholars can indeed make a contribution to the understanding of religion ( $p^{\prime}$ Bitek, cited in Maluleke 1998:125), but conditionally, depending on the use of acceptable methodology (cf. Westerlund 1993).

Then there are scholars who hold that Africa is the place of origin of all religion (Krüger 1995:174). In this regard, religion itself becomes the contribution Africa makes to humanity. Krüger's theory (1995:174) is based on archaeological findings that Africa is the cradle of humankind and, therefore, the origin of pure religion. Such a point of view is difficult to defend, as it can easily be challenged by the next archaeological discovery.

There are also those who would point out that an African understanding of religion can at times be nothing more than an internalisation of Western thought and ideas on what religion is ( $\mathrm{p}^{\prime}$ Bitek, cited in Maluleke 1998:125).

Do African scholars indeed have a different understanding of what religion is? Is the African understanding of religion merely a way to focus on different characteristics of religion? Or is religion universally defined similarly, merely differing on issues such as the function and structure of religion? Is the difference in opinion on what constitutes religion based on cultural elements, which are arranged differently according to each culture? This article attempts to investigate a contribution from an African understanding of what religion is.

Africans did not invent religion. The appeal of the transcendence of the human spirit is universal and the response to this is varied. This investigation focuses on the response from an African perspective. Indeed, an African understanding of religion can contribute to the universal phenomenon of religion, in that

African traditional religion ... is part of the religious heritage of humankind. Born out of the experience and deep reflection of our African forebears, it provides answers to the stirring of the human spirit and elaborates on the profundity of the experience of the divine-human encounter based on the resources of Africa's own cultural heritage and insight.

(Opoku 1993:67)

Opoku (1993:67) points out that Africa's interpretation of reality does contribute to the understanding of human existence and the divine. This interpretation of reality is already an indication of how African Traditional Religion values other religious traditions: 'the divine truth is beyond the reach of a single religious tradition' (Opoku 1993:67). Therefore, the African understanding of the plurality of religion can be described as the acceptance of the equality of religions. As Turaki (1999:29) argues, pluralism and parity of all religions are accepted. Truth has its source in God and not in humans. The understanding of divine truth can, therefore, not be restricted to one religious tradition (Opoku 1993:67).

'The religious heritage of Africa shares the same religious concerns with other religions of humankind, providing a source for man's search for knowledge of God' (Opoku 1993:80). By listening to the religious experience of others, one's own understanding of religion is broadened.

\section{THE PROBLEM WITH A DEFINITION}

What is religion? The answer to this question usually reveals more about the one giving the definition than about religion itself (Sundermeier 1999:11). Our perspective determines our theory or definition of religion. A sociologist would look through a sociological lens at religion, whereas a psychologist would give a definition based on a different (psychological) perspective. This would also apply to culturally determined definitions: a Westerner would provide a definition influenced by European thought and an African would formulate the answer according to African philosophy.

There are many traps on the road to defining religion. A definition that is too broad (a maximum definition) would include elements not usually associated with religion. One that is too narrow (a minimal definition) would exclude those elements that are normally accepted as religion. On the possibility of defining religion, there are those who would suggest abandoning the term religion (Asad, cited in Figl 2003:71) and those who feel that religion is ideology per se (Lease, cited in Van den Heever 2001:2). Lease considers religion to have no independent existence apart from an academic exercise (Van den Heever 2001:2).

Religion is socially constructed. Humans form religion by way of making choices and selections (Van den Heever 2001:3). Religion is the human way of representing reality (Van den Heever 2001:4). It is therefore quite logical that there will be a multitude of interpretations of what reality looks like. Religion is not seen as something concerned with a specific phenomenon (Van den Heever 2001:3).

Turaki (1999) lists a number of attempts at defining religion:

- Ray indicates that religion is a 'meaning system' or a 'theory of meaning' (Turaki 1999:70).

- For Geertz, religion is a 'cultural system' (Turaki 1999:89).

- Idowu says religion is the means by which God as a spirit and man's essential self communicate'. Idowu therefore sees religion as the result of humanity's spontaneous awareness of a living Power (Turaki 1999:70-71).

- Steyne maintains that religion is a 'search for relationship to and with the supernatural' (Turaki 1999:73).

- Turaki (1999:71) asserts that religion consists of a 'theory of being and a theory of meaning'.

Without adding to the long list of existing definitions of religion, this study does require a point of departure. A preliminary definition, influenced by an African understanding of religion, would be to describe religion as the continual participation in traditions (myths and rituals) passed on from one generation to the next. This functional definition will form the working definition in this study.

It is necessary to be aware of the traps, as mentioned above, in defining religion. These traps make one aware of the limitations of all definitions of religion. An African understanding of religion can therefore only enrich and not replace existing understandings of religion.

\section{UNDERSTANDING AFRICAN RELIGION}

Is there one religion in Africa? Africa does not present itself as one united front of ideas and religion. The historical development of 
Africa allowed a multitude of influences. 'If Africa is anything, it is various and there are million ways of being an African' (Maluleke 2001:37). Religiously, as well as a culturally, there is huge diversity on the vast continent of Africa; Africa consists of 'multiple identities' (Maluleke 2001:37).

It is generally accepted that there are many religious systems in Africa (Magesa 2002:16; Mbiti 1990:1). It therefore is impossible to talk of one type of religion as being uniquely African. There is diversity in religious concepts and practices in Africa and it will therefore not be incorrect to talk about different African religions (plural) (cf. Krüger, Lubbe \& Steyn 2009:35).

Mbiti argues that, although the religious expressions in Africa are multiple, the philosophy underlying religious life is singular (Mbiti 1990:1). Krüger et al. (2009:35) concede to this fact: 'religions of black Africa are similar enough to talk of African Religion in a generic sense. They also share a sufficient number of characteristics'. There seems to be a coherent philosophy underlying the different expressions of religion in Africa. The expressions of thought may vary and differ, but they still remain expression of basic belief (Magesa 2002:17).

In this article, reference has already been made to the African attitude to the plurality of religion (cf. Introduction): equality of religions, pluralism and parity of all religions are accepted (Turaki 1999:29). There is salvation outside of the (Christian) church and without Christ (Turaki 1999:29). God is seen as 'the Father of not only humanity in general (individuals) but also of the religions and cultures of all peoples in the world' (Turaki 1999:29). Therefore, all religions in Africa have a right to exist and make a valuable contribution to the understanding of the divine.

\section{Characteristics}

Although varied in outward appearance, African religions display similarities. There have been many attempts at describing African Traditional Religion according to its main characteristics. Turaki (1999:69) lists the following main characteristics:

- belief in a Supreme Being

- belief in spirits and divinities

- the cult of ancestors

- the use of magic, charms and spiritual forces.

Krüger et al. (2009:35-39) identify the following three common traits of African religions that enable scholars to talk of African Religion (singular):

- belief in a Supreme Being

- the realm of spirits

- a unified community.

Taking the above efforts into consideration, it would be fair to describe the most common elements of African Traditional Religion under the following headings.

\section{The belief in transcendence}

The definition of religion, as understood by Sundermeier (1999), is helpful in understanding African Traditional Religion. Sundermeier (1999:27) sees religion as the communal answer given to the experience of the transcendental and its manifestation in rites and ethics. According to this definition, the existence of the transcendental is accepted a priori. This is also the case in African Traditional Religion (Magesa 1997:40). It is necessary to maintain a vague understanding of the transcendental, as it may refer to a dynamistic power and/or a personal god. Rites are part of the social structure of religion. Ethics, Sundermeier (1999:27) points out, does not have its origin in humanity and must be understood as an essential element of religion. African Traditional Religion has a specific understanding of the origin and function of ethics.

\section{The transcendental in terms of life force}

African Traditional Religion is strongly based on belief in impersonal power. This dynamistic understanding of the universe influences all human behaviour. Turaki (1999:78) points out how this power has been given many different names in the past: mana, life force, vital force, life essence and dynamism. Higher mysterious powers, called the mysterium tremendum by Smith (cited in Turaki 1999:78), fill objects with power that can have either a positive or negative effect on people.

Magesa (1997:35) points out that the structure of African Traditional Religion is based on morality. Morality originates with God and flows into the ancestors. God is the 'Giver of Life, the Power' behind everything (Magesa 1997:35). The way of human life (tradition) originates from God (Magesa 1997:35). Tradition contains the moral code and prescriptions for an ethical life.

The transcendental is experienced as an immanent reality by way of providing the moral code for human life. The African understanding of morality is based on a cosmological understanding. The universe consists of two spheres, the one being visible and the other invisible. The visible world is creation as we perceive around us. The invisible world is the residing place of God, the ancestors and all the spirits and powers. The inhabitants of the invisible world are called the 'forces of life' or 'vital forces' by Tempels (cited in Magesa 1997:39). The ultimate power is God, the Creator, the provider of ethics and traditions. God provides every living thing with its 'own force of life, its own power to sustain life' (Magesa 1997:46). All living beings are interconnected through this life force. All living things receive the energy for life from the same source. (This connectedness is emphasised in the discussion on community that will follow.) The whole purpose of life in African Traditional Religion is to preserve and enhance this life force that everyone has received (Magesa 1997:51). Moral behaviour maintains and enhances life force, but disobedience and disloyal behaviour toward the tradition passed on by the ancestors will weaken life force. The whole purpose of African life is to ensure the capacity of this life force. A close relationship with God, the ancestors and other humans will ensure life force (Magesa 1997:52).

The capacity for life force is not only threatened by an immoral life, but also through the evil working of spirits (Magesa 1997:53). Spirits can be employed to bring harm to others and to tap the life force of others. The same spirits can be implored to protect one from the evil intentions of others.

African Traditional Religion, according to Magesa, is based on maintaining the balance between the two spheres of the universe (the visible and invisible world). The maintenance of this balance and harmony is humanity's greatest ethical obligation and determines the quality of life (Magesa 1997:73). Humans live through the connectedness with the life force that God, the Supreme Being, provides.

\section{The transcendental in terms of a Supreme Being}

Fundamental to definitions of religion is the acknowledgement of the existence of the transcendental and human reaction to it. The transcendental also features in African Traditional Religion.

According to Mbiti's monumental research (1970:3) on the African perception of a deity, God takes the highest possible position. Although perceived as omniscient, omnipresent, omnipotent, transcendental as well as immanent, God is more accurately defined as being 'incomprehensible and mysterious' (Mbiti 1970:26). God is acknowledged as creator (Mbiti 1970:45; 1990:39, 91). Although there are many different myths relating to the exact act of creation, it is seen as an activity where God is the acting subject. God (and his creation) has no beginning and no end (Opoku 1993:70, 73). He is accessible to all humankind (Opoku 1993:70-71).

God is spirit (Sundermeier 1990:175). The African perception of the existence of a deity has long been held to be polytheistic, but, as Sundermeier (1990:186) points out, more and more scholars 
accept African Religion as monotheistic. God does not require a name (Sundermeier 1990:187). To name someone is considered an act of control over that entity. Therefore, in Africa, God is designated by an ancient term, sometimes from another culture, or a unique name (Opoku 1993:71). By not giving God a specific name, the dignity of God is maintained (Sundermeier 1990:187) God continues to provide for his creation in order to sustain existence.

The theistic approach of African Religion is questionable. Although a common Supreme Being is identified, known by different names in different cultures, and although this being is perceived personally, contact with this God is only possible through mediators or councillors (Krüger et al. 2009:36). The way in which the mediator is approached and venerated is an indication of the devotion to God (Krüger et al. 2009:36).

Redemption is mediated. This creates the idea of deism. God is seen as absent and rarely able to assist or advise followers. Mbiti (1970:171) records how many traditions in Africa relate to the origin of the separation between God and humanity. The most common traditions relate how humanity disobeyed the commands given by God. As punishment, God withdrew from humanity (Mbiti 1970:176, 1990:95). God is perceived still being active in human history, however, not having forsaken humanity entirely (Mbiti 1990:47).

God may be recognised as creator (currently transcendent) and sustainer (immanently involved with his followers), but is not seen as the focus of all attention, as the mediators attract more attention. Mbiti (1970:12) refutes the assumption that God is only absent and transcendental by indicating that God can simultaneously be far (transcendental) and near (immanent). For Africans, Mbiti argues, this plays out as follows:

For most part of their life, African people place God in the transcendental plane, making him seem remote from their daily affairs. But they know that he is immanent ... Thus for them, God is in theory transcendent, but in practice immanent.

(Mbiti 1970:18)

Mbiti points out that the position God takes in African religion is not necessarily that of Redeemer (1990:96). As there is no threat or condition from which humanity is in need of deliverance or redemption, African Traditional Religion sees worshipping God as imploring the Provider to keep on doing so. God is not worshipped in order to gain redemption or salvation (Mbiti 1990:97)

\section{The transcendental as the realm of spirits}

African religion, among other religions, has been accused of being animistic (Momen 2009:357). The conviction that reality as perceived by humanity is merely a part of reality, and the fact that an invisible spiritual world co-exists with the visible world characterises African Traditional Religion as animistic An undying spirit cannot only inhabit humans, but also inhabits inanimate objects. After death the human spirit returns to its place of origin in the spiritual world. This conviction makes no distinction between the physical world and the spiritual world, creating a holistic worldview: everything and everyone is connected to everything and everyone else.

Krüger et al. (2009:36) identify three categories in the spirit world of African Traditional Religion, namely the spirits of ancestors, nature spirits and deities. Although the border between spirits and gods is perforated (Sundermeier 1990:175), there are differences between the two categories. Spirits roam on earth (Sundermeier 1990:175). Gods, on the other hand, are closer to God and have a wider sphere of influence and activity. Gods might possess divine characteristics. Gods live further away from earth than spirits; gods reside in heaven, although there are some gods residing on earth. Some of the minor gods in African cultures may be seen as children of God (Sundermeier 1990:178).
The belief in ancestors is central to traditional African thought and is an essential pillar of religion practised in Africa (Stinton 2004:133-134). There are many different ways in which this acknowledgement of the existence of the deceased is expressed. Africa is not the only continent where cultures have the religious practice of venerating and worshipping ancestors (cf. Bae 2007:1). Although this phenomenon takes on different forms among different ethnic groups in Africa, Nyamiti identifies certain common traits of ancestral beliefs (cited in Stinton 2004:134). These include:

Natural relationship: The natural relationship between the ancestor and the earthly descendents is usually that of parent and offspring. Children consider parents and grandparents as direct ancestors.

Supernatural or sacred status: Ancestors automatically acquire some kind of supernatural power. This is based on the dynamistic and animistic worldview in Africa. The spirits of ancestors are not merely impersonal powers reigning over some holy domain. Ancestors have a personal relationship with their descendents. Ancestors can be approached, from time to time, for advice on personal issues. Ancestors are worshipped and venerated ambiguously. Ancestors are simultaneously feared and adored. The same ancestors that can bestow gifts of good fortune can also cause harm and misfortune for those who neglect to acknowledge the ancestors.

Mediation: From a hierarchical position that is superior to humans, ancestors are inferior to God and act as mediators between God and humans. Even holy functionaries like traditional healers operate through the mediation of ancestors (Mbiti 1990:84). Ancestors are not of divine nature. Together with their descendants, ancestors worship God (Stinton 2004:135). As mediators between God and humans, ancestors do not possess the power to mediate salvation.

Sacred communication: Ancestors remain in contact with descendants for quite some time. It is believed that they still take part in the daily routine of the family (Mbiti 1990:82). Ancestors are mostly acknowledged for up to four or five generations, whereupon the memory of these ancestors dies out and they are considered to be truly dead (Mbiti 1990:83). The spirit of the deceased then becomes an impersonal spirit residing in the spirit world.

Exemplarity: Ancestors are considered to be good models for human behaviour. Their acts of virtue are seen as good examples of proper life. Their way of life educates the living on proper social behaviour.

Not all the living have the privilege of becoming an ancestor. Two conditions are identified by Sarpong (cited in Stinton 2004:134-135). These are, (1) one must pass through all stages of life to attain adulthood, which is only considered to arrive once one has had children and therefore transmitted life and (2) one must die a natural death. Death by accident, suicide, unclean diseases or in childbirth is not considered a good death.

Stinton (2004:135) identifies three distinct functions of ancestors. Shorter (cited in Stinton 2004:135) calls the first function that of 'liturgical companions to the living'. The second function is to operate as mediators between God and humans. According to Stinton, Mbiti (1990:85) refers to the third function of ancestors as guardians of family affairs, traditions, ethics and activities.

Companions on the journey of life: Africans have a circular understanding of time (Mbiti 1990:17). Life is the rhythmic progression through the stages of life. All humans are subject to these phases, which include birth, puberty, adulthood, old age and death. To assist the successful completion of the cycle of life, the ancestors act as guides on this journey. At the onset of every 
stage there are rites of passage to be performed to initiate one into the next phase. Ancestors play a spiritual role in these rites. Some, like Bujo (cited in Stinton 2004:141), interpret the role of ancestors at these rites of passage as the mediation of salvation.

Ancestors have set the example of a successful completion of the process. Now they can provide advice on how to travel on this journey. In this sense, the ancestors become the spiritual guides for people. By ignoring the ancestors, one demonstrates arrogance and self-reliance in the course of the journey of life. Neglecting the ancestors in this way is punished with misfortune.

Mediators: Ancestors act as mediators between God and humans. Nürnberger (2007:29) illuminates this aspect very clearly when he presents the knowledge of African people of the transcendental world as a 'pool of power'. The Supreme Being (God) would then be the culmination of this pool of power and not necessarily a person (Nürnberger 2007:29). In other words, the Supreme Being can be described as 'the peak of the spiritual hierarchy' (Nürnberger 2007:33). The spirits of the deceased ancestors reside in this deistic and dynamistic spiritual realm.

In the social structure of African cultures it is difficult for a person to approach a higher-ranking individual, for instance the village chief. Intermediaries are necessary. In the same fashion, ancestors function as the 'go-betweens' between humans and God (Nürnberger 2007:33). Nürnberger is of the opinion that the ancestors do not act on behalf of the Supreme Being and do not mediate sacrifices or the prayers directed by humans to the Supreme Being. At most, the ancestors derive their supernatural power from the 'pool of power' (Nürnberger 2007:33). The ancestors themselves become the authority that bestows advice and blessings (and misfortune) upon humans (Nürnberger 2007:33). Ancestors thus seem only to mediate the power emanating from the Supreme Being.

Guardians of traditions: It would seem as if ancestors function as the social conscience of a community. The norms and moral values given by the ancestors assist individuals to live a proper life (Magesa 1997:35). The example set by the ancestors ensures a harmonious community where everybody knows and understands their place and function. In doing so, there is continuity with the past and the social structure of the extended family is maintained. In this way, the ancestors are guardians of traditions (Mbiti 1990:85; Nürnberger 2007:29).

Psychological interpretation: From a psychological point of view it seems as if there is a close bond between ancestors and descendents. Individuals frequently consult the ancestors for advice on daily decisions. This sense of dependence on the permission and advice of the ancestors provides individuals with comfort and security. Advice from the ancestors helps humans to cope with the struggles and stresses in their lives. This dependence on ancestors also creates a sense of belonging and identity. People know who they are, as well as who the people they encounter are, on the basis of the identity of the ancestors.

\section{The sanctity of a unified society}

As a third main characteristic of African Traditional Religion, Krüger et al. (2009:38) emphasise the unified community. African Traditional Religion exhibits a specific social understanding of the place of the individual in community. There is a dynamic natural bond between the individual, the extended family, the clan or the tribe, and the ancestors, nature and God (Krüger et al. 2009:38). This is not merely a social understanding, but extends ontologically. To this list, Thorpe adds the relationship with coming generations (Thorpe 1991:120), while Sundermeier (1990:22) extends the list to include a connection with the mineral world.

The effects of this communal solidarity are far-reaching and include:

Identity: In Western thought, to exist is to maintain individuality. Personal growth is restricted to an internal process. To be part of a group is secondary. In African thought, the opposite is true. Individuals can only exist when they are part of a group (Sundermeier 1990:26). As Thorpe (1991:120) argues,' [i]ndividuals cannot exist alone. They are because they belong'.

The group is where religion happens. Membership of a social community immediately means membership of a religious community. Religion binds and does not divide a community (Opoku 1993:77). The group not only shares similar sacred beliefs and practices, but religion determines every aspect of community life (Opoku 1993:77). The group becomes a sacred community (Mbiti 1990:200). The sanctity of the community is maintained by regulations pertaining to proper behaviour. Improper or unjust behaviour toward fellow members of the community disrupts harmony and damages the sanctity of the community. Only through ritual reparation can sanctity and harmony be restored. That which is to the advantage of the group supersedes individual wishes.

Continuity: The sanctity of the community stretches across the borders of life and death. Every generation and every individual is merely a part of a never-ending chain that stretches backward into the past and forward into the future. This connection with the past places the responsibility for the continuation and preservation of the traditions of the past on the shoulders of the current community. Life never ends; so also does the continuity of the religious heritage know no beginning and no end. The community is bound to the past and the future through the continuation of worshipping the God of the ancestors. The worship binds generations together.

Interdependence: The holistic worldview of Africa that portrays humanity as being connected to all living and non-living entities (cf. Magesa 1997:46) implies a universal interdependence. Sundermeier (1990:27) views this as reciprocal dependency. All living things share in the gift of life (Sundermeier 1990:22) and are therefore bound in fate. The death of one provides the other with life. This is most obviously seen in a hunter-gatherer community. Animism provides further arguments for this interdependence of humans and nature. There is a spiritual bond between humans, animals and plants. This could have resulted in the European designation of African religion as totemistic (Mbiti 1990:10).

Man's inescapable bond with nature implies a heavy burden of responsibility for the conservation of nature (Opoku 1993:77). Humans, due to their ontological (even teleological) position in nature are obligated to take care of nature. Opoku (1993:78) stresses the contribution that African Traditional Religion makes to the worldwide concern with the environment. Momen (2009:356), on the other hand, points out that it is presumptuous to think that followers of African Traditional Religion will have a greater sense of ecological responsibility. People belonging to an African religion do indeed have closer ties with nature, but the exploitation of nature is not excluded. Seeing nature as organic and spiritual and seeing humans holistically interconnected with nature can at times be a Western interpolated interpretation of African Religion. The African understanding of religion emphasises the sociological aspect of religion.

\section{Homo ritualis}

Human life is determined by rites. Knowingly or unknowingly, humans participates in the continuation of socially constructed actions, based on a familiar or unfamiliar reason for the actions (myths), which enables them to journey through life.

There are different dimensions to the understanding of rites. These include dimensions that are social, creativeaesthetic, involve repetition and connection with the past, are pedagogical, provide identity and are judicial and religious (Sundermeier 1999:87-88). All rites within primal religion (also African Traditional Religion) possess a religious dimension (Sundermeier 1999:88). 
Rites are undeniable an integral part of religion. There is no known religion without ritual (Sundermeier 1990:67). As rites are to be understood multidimensionally, an understanding of rites contributes to insight into religion as well as an understanding of sociology and anthropology (Sundermeier 1999:84). The term 'rite' refers to a form of religious expression (Sundermeier 1990:67) and to the arrangement and ordering of relationships within society (Schmidt 1980:149). Rituals help to give structure and meaning to life (Thorpe 1991:121).

At the base of rites lie myths (Widengren 1969:209). Myths provide the theoretic background to the meaning of rites. Behind a rite lies the reality of a past event. The myth is the recounting of this event. Without a myth to support it, Widengren (1969:210) points out, a rite will become a mechanical act or even die out completely. Myths and the rites associated with them are transferred from one generation to the next to ensure the continuation of the (religious) tradition. Myths are the vehicle that ensures the handing over of tradition from one generation to the next (Magesa 1997:36)

Rites are communal activities that occur when the individual celebrates relationships with the other (the community, the transcendental and the self). Although the symbols in rites remain constant, the interpretation of rites is different within every community (Sundermeier 1990:67). Rites do not have only a religious meaning, although the social and religious aspects are closely interwoven in rites (Sundermeier 1990:80). Sundermeier (1999:88) points out how rites in some religions have developed a profane character. The implication is that some rites may become separated from their religious meaning. Through religious rites, humans 'leap into the framework of the sacred' (Schmidt 1980:150). Rites then become the bridge to the invisible (Sundermeier 1999:89).

Africa is a continent filled with rituals and symbols. Rituals, filled with symbols, often take on the form of dramatic presentations among African people (Thorpe 1991:121). The nature of African religion lies not in dogmatic constructs or philosophically (theologically) formulated doctrines, but, rather, African Traditional Religion lives in the hearts and lives of people who practise it (Opoku 1993:68). For African Traditional Religion, rites, the things that we 'do' in religion, are more important than the things that we believe.

Of course, the fear of reductionism hangs in the air. This study does not want to reduce the understanding of religion only to knowledge of rituals. Sundermeier (1999:84) reminds us of the threat of over-emphasising the study of rites. Rites stand so central in the study of religion that they, at times, threaten to replace the study of religion altogether. This study is well aware of that threat.

\section{AFRICAN UNDERSTANDING OF RELIGION}

What insights into the nature of religion have we gained from this brief description of African Traditional Religion? Mbiti (1975:10) identifies five elements as being constitutive of all religion: beliefs, practices (ceremonies and festivals), objects and places, values and morals, and religious officials. Mbiti (1975:12) tries to analyse the nature of religion seen through an African lens along these lines. Religion, for Africans, is the normal way of looking at the world and experiencing it, for it is so much part of human existence that it is not seen as something separate.

\section{A profound unity}

The African understanding of religion is an understanding of the connectedness of all things. This also becomes clear from an African worldview. There is a close relationship between all things. There is one reality, with no distinction between physical and spiritual. Meaning in life is derived from unity. Rituals are an expression of this unity. Morals and ethics are concerned with maintaining unity. Religion, therefore, does not keep this unity intact - it is the expression of this unity. Religion is not the method by which to create unity but the celebration of unity.

An African understanding of religion holds that religion is reality and reality is religion. There is no separation between spheres of reality. The transcendence (God(s), powers, spirits) is just as much part of reality as the visible elements in the world. Religion can never be perceived as a separate fragment focused on a different 'reality'. Magesa (1997:52) illustrates this by pointing out that, for Africans, 'the universe is perceived as an organic whole'. In African religion, 'humans maintain the bond between the visible and invisible spheres of the universe' (Magesa 1997:72). The concept of the unity of body and spirit is true not only of ancient Greek philosophy and Hellenistic anthropology, but also applies to African Religion (Wernhart 2003:269).

Okot p'Bitek, a staunch protector of African culture, describes African Traditional Religion as religion not concerned with metaphysics, but with the 'this-worldly' (cited in Maluleke 1998:127). African Traditional Religion experiences religion as being actively part of the experienced world. Religion is not a structure created to reflect a metaphysical (virtual) world. An African understanding of religion draws no distinction between reality and virtuality (Wernhart 9003:265). p'Bitek (cited in Maluleke 1998:127) therefore argues that there is no such thing as animism. Animism creates the idea of a second, virtual, plane of existence. There is only one world, one reality, and religion is part of this reality.

A distinction between culture and religion betrays a Western understanding of religion (Sundermeier 1999:11). African Traditional Religion sees religion as the foundation of all life; it is, as Thorpe (1992:3) argues 'an integral part of life itself'. There is no differentiation between the sacred and the profane (Thorpe 1992:3; Wernhart 2003:269). Everything in life has to do with religion. Mbiti (1990:1) states that '[r] eligion permeates into all the departments of life so fully that it is not easy or possible always to isolate it.' To this one could add Thorpe's view (1991:28) that '[a]ll of nature is invested with a mystical, religious quality'. All of reality is one. Everything (animate and inanimate) forms part of a living community. This holistic understanding of reality holds that all elements in nature (i.e. animals, plants, rivers, mountains etc.) have religious significance and must be treated with respect. Of course this creates a dilemma: the traditional African understanding of religion acknowledges the existence of an invisible spiritual world and simultaneously maintains that all things are united and interconnected (Thorpe 1992:112).

Carmody (1981:73) introduces the concept of 'consubstantiality' to describe this profound unity. All creation shares a common substance; there is no real differentiation between 'rocks and plants, plants and animals, animals and human beings, human beings and gods' (Carmody 1981:73). The whole cosmos is perceived as a single living system. There is no separate reality existing outside of the cosmos. This belief, known as the cosmological myth (Carmody 1981:60, 73), still underlies the African understanding of religion. It implies a core unity of all that exists. This further implies a monistic origin of all that exist; an equality of essence of all things.

The implication would be that there is no hierarchy in creation. Humans have no superiority over nature or any other element. Humans are in the world, part of the world, but transcend the world. This gives humans an extra responsibility to take care of the world. Such an understanding of religion provides the moral ground for pleading for the conservation of nature.

The African worldview is described as a religious worldview (Bediako 1995:29; Mbiti 1990:15). The world is perceived through a religious lens. Every activity and entity has religious significance. The elemental, spiritual and communal forces (the cultural heritage of Africa) have become not merely the locus of 
divine revelation to the African, but also the means of the human response to the divine disclosure (Bediako 1995:29). Humans are part of the world where spirits and gods reside. Religion is therefore not a separate entity existing to be defined apart from life. Idowu (cited in Turaki 1999:70-71) describes religion as the result of humanity's spontaneous awareness of a living Power. Religion is interwoven with human (cultural) existence in the world.

According to an African understanding of religion, to be human is to be religious; to live is to be religious.

\section{Meaning}

Religion is an effort by humans to search for meaning, to understand reality and place themselves in a relationship with reality. Religion is therefore an epistemological activity. Religion is not only an intellectual, cognitive experience, as at times happens in Western culture. Religion encapsulates the whole human being. Humans stand in a holistic relationship with reality. All of life has to do with religion. Sundermeier (1991:11) attests to this by saying that religion is the foundation of all life. Religion is 'the source of life and meaning' (Opoku 1993:79).

Meaning, according to an African understanding, is always understood in a spiritual way (Turaki 1999:124). The important questions in life revolve around the spiritual and not the physical (Turaki 1999:124). All events in life are understood as having spiritual significance. There is a close connection between meaning and morality: 'The pursuit of spiritual meaning is one of the moral laws which govern the morality and ethics of man in traditional Africa' (Turaki 1999:124).

Religion becomes the way in which humans express an understanding of reality and the search for the meaning of life. The understanding of reality is religiously predetermined: 'To be is to be religious in a religious universe' (Mbiti 1990:256). According to the African understanding, an understanding of reality cannot be a mere clinical, scientific analysis of the material. There exists only one reality and part of it is invisible. Meaning in life is found this-worldly, in this reality. To ignore or neglect the existence of the transcendental will create disharmony in reality and will deprive the experience of the meaning of life. The pursuit of cosmic harmony is an ethical principle in traditional Africa (Turaki 1999:122).

\section{Rituals}

In understanding reality and maintaining a relationship with reality, humans express these experiences in the form of rites (Sundermeier 1999:11). Humans are ritualistic beings. Rituals become the symbolic actions that define the relationships in which humans stand; not only relationships with the divine, the ancestors or spiritual beings, but also societal relationships with other humans and with nature and everything therein.

Ray (cited in Turaki 1999:69-70) states that '[t]he ritual sphere is the sphere par excellence where the world as lived and the world as imagined become fused together'. Ritual, therefore, is the action of symbolically expressing human unity with the universe; a confirmation of the consubstantiality, so to speak. Symbolism flows from the belief that there is no division between the profane and the sacred. Everything, no matter how profane it seems, has sacred significance.

\section{Values}

Human existence is always existence in community. Morality is therefore not a selfish action directed at one's own benefit, even though there are scholars who hold that traditional religions are focused on humanity's selfish needs (Turaki 1999:129). All humanity's societal behaviour carries religious significance. Religion functions as a moral and ethical foundation (Turaki 1999:122). Turaki identifies moral principles in the traditional worldview as the pursuit of cosmic harmony, the pursuit of spiritual meaning, the pursuit of mystical powers and the pursuit of kinship community (1999:122). These moral principles fit into the framework of an African understanding of religion.

In understanding reality and maintaining a relationship with reality, humans express the experience of the transcendental in the form of norms (Sundermeier 1999:11). Morals indeed assist humans in maintaining harmony with their entire environment (Mbiti 1975:11).

Religious morals and values provide identity. In the religious way of life, people discover who they are and where they come from (Mbiti 1975:13). Morals and values provide security for a harmonious existence. Religious values and morals give direction and provide answers to life's questions. In this sense, religion becomes the roadmap for human existence (cf. Van den Heever 2001:16).

\section{CONCLUSION}

This study does not want to bring about an exchange. This is not an effort to replace the existing (Western-dominated) understanding of religion with a new (predominantly African) understanding of religion. Rather, this is an effort at enhancing the understanding of religion by recognising the contribution that African thought has made to the understanding of religion. This addition of insights should bring about a broader understanding of religion.

An African understanding of religion emphasises:

- a holistic approach to understanding unity

- the importance of the meaning that religion creates

- religion as the framework within which rituals should be understood

- religion as the background against which social values should be understood.

Religion is universal. Religion is expressed contextually according to local culture. The phenomenon of religion is understood differently according to different thought patterns. For a long time, religion has been understood solely according to Western thought patterns. This article pleads for a broader scope of understanding religion by including insights from an African point of view.

\section{REFERENCES}

Bae, C.S., 2007, Ancestor worship and the challenges it poses to the Christian mission and ministry, $\mathrm{PhD}$ thesis, University of Pretoria.

Bediako, K., 1995, Christianity in Africa: The renewal of a non-Western religion, Edinburgh University Press, Edinburgh.

Carmody, D.L., 1981, The oldest God: Archaic religion yesterday $\mathcal{E}$ today, Abingdon, Nashville.

Crosby, D.A., 1981, Interpretive theory of religion, Mouton Publishers, New York.

Figl, J. (ed.), 2003, Handbuch Religionswissenschaft: Religionen und ihre zentrale Themen [Handbook of religious studies: Religions and their central themes], Tyrolia-Verlag, Innsbruck.

Hammer, D.H., 2005, The God gene: How faith is hardwired into our genes, Anchor Books, New York.

Krüger, J.S., Lubbe, G.J.A \& Steyn, H.C., 2009, The human search for meaning: A multireligion introduction to the religions of humankind, Van Schaik Publishers, Pretoria.

Krüger, J.S., 1995, Along edges: Religion in South Africa: Bushmen, Christian, Buddhist, University of South Africa, Pretoria.

Magesa, L., 2002, African religion: The moral traditions of abundant life, Orbis Books, Maryknoll.

Maluleke, T.S., 1998, 'African traditional religions in Christian mission and Christian scholarship: Re-opening a debate that never started', Religion and Theology 5(2), 121137. 
Maluleke, T.S., 2001, 'Identity and integrity in African theology: A critical analysis', Religion and Theology 8(1), 26-39.

Mbiti, J.S., 1970, Concepts of God in Africa, SPCK, London.

Mbiti, J.S., 1975, Introduction to African religion, Heinemann, London.

Mbiti, J.S., 1990, African religions and philosophy, 2nd edn., Heinemann Educational Publishers, Oxford.

Momen, M., 1999, Understanding religion: A thematic approach, Oneworld Publications, Oxford.

Nürnberger, K., 2007, The living dead and the living God, Cluster Publications, Pietermaritzburg.

Opoku, K.A., 1993, 'African Traditional Religion: An enduring heritage', in J.K. Olupona \& S.S. Nyang (eds.), Religious plurality in Africa: Essays in honour of John S. Mbiti, n.p., Mouton de Gruyter, Berlin.

Schmidt, R., 1980, Exploring religion, Wadsworth, Belmont.

Stinton, D., 2004, Jesus of Africa: Voices of contemporary African Christologies, Paulines Publications Africa, Nairobi.

Sundermeier, T., 1990, Nur gemeinsam können wir leben: Das Menschenbild schwarzafrikanischer Religionen [Only together can we live: The humanity of Black African religions], Gütersloher Verlagshaus Gerd Mohn, Gütersloh.
Sundermeier, T., 1999, Was ist Religion? Religionswissenschaft in theologischen Kontext [What is religion? Religious studies in a theological context], Chr Kaiser Gütersloher Verlagshaus, Gütersloh.

Thorpe, S.A., 1991, African Traditional Religions: An introduction, University of South Africa, Pretoria.

Thorpe, S.A., 1992, Primal religions worldwide: An introductory descriptive review, University of South Africa, Pretoria.

Turaki, Y., 1999, Christianity and African gods: A method in theology, Potchefstroomse Universiteit vir Christelike Hoër Onderwys, Potchefstroom.

Van den Heever, G., 2001, 'On how to be or not to be: Theoretical reflection on religion and identity in Africa', Religion and Theology 8(1), 1-25.

Wernhart, K.R., 2003, 'Ethnische religionen [Ethnic religions]', in J. Figl (ed.), Handbuch Religionswissenschaft: Religionen und ihre zentrale Themen, Tyrolia-Verlag, Innsbruck.

Westerlund, D., 1993, 'The study of African religions in retrospect from "Westernization" to "Africanization"', in J.K. Olupona \& S.S. Nyang (eds.), Religious plurality in Africa: Essays in honour of John S. Mbiti, n.p., Mouton de Gruyter, Berlin, New York.

Widengren, G., 1969, Religionsphänomenologie [The phenomenology of religion], Walter de Gruyter \& Co, Berlin. 